\title{
DETERMINAN KOMPLIKASI OBSTETRI DI INDONESIA (ANALISIS DATA SDKI 2012)
}

\author{
Serilaila $^{1}$, Sri Yaniarti ${ }^{2}$, PS. Kurniawati ${ }^{2}$, Demsa Simbolon ${ }^{3}$ \\ ${ }^{1} J u r u s a n$ Kebidanan Poltekkes Kemenkes Banjarmasin, ${ }^{2} J u r u s a n$ Kebidanan Poltekkes \\ Kemenkes Bengkulu, ${ }^{3} J u r u s a n$ Gizi Poltekkes Kemenkes Bengkulu \\ e-mail:serilaila11@yahoo.co.id
}

\begin{abstract}
Maternal mortality rate in Indonesia data IDHS on 2012 is still high at $359 / 100,000$ live births, an increase of $57 \%$ compared to IDHS in 2007 . One cause is due to obstetric complications. Compared to the 2002 and 2007 IDHS data, this figure is increasing and many factors affect the occurrence of obstetric complications. The objective is to know the determinant of obstetric complication based on IDHS data of 2012. This research use secondary data with cross sectional approach based on survey of IDHS 2012 with 4,618 samples. Result: Obstetric complicationwere $51,2 \%$ and there was significant correlation social of economy, parity, distance birth, history of complication, residence area, place of labor and quality of ANC to the obstetric complication. Result of research showed that there were correlation history of complication before $\mathrm{OR}=4,084$, quality of $\mathrm{ANC} \mathrm{OR}=1,187$, place of labor $\mathrm{OR}=1,517$, birth and parity spots interact with village residence against obstetric complications. Expected to improve quality services of ANC and ability of health worker to handle reference cases and improving readiness mother and family for recognize and anticipate incident of obstetric complication especially for mother who are at risk.
\end{abstract}

Keyword :Determinants,Obstetric Complication

Abstrak:Angka kematian ibudi Indonesia Data Survei Demografi Kesehatan Indonesia (SDKI) tahun 2012 masih tinggi, yaitu 359/100.000 Kelahiran Hidup, angka ini meningkat $57 \%$ dibandingkan tahun 2007 . Salah satu penyebabnya komplikasi obstetri. Dibandingkan data SDKI 2002 dan 2007 angka ini meningkat dan banyak faktor yang mempengaruhi terjadinya komplikasi obstetri. Tujuan penelitian untuk mengetahuideterminan komplikasi obstetri berdasarkan data SDKI tahun 2012.Penelitian ini menggunakan data sekunder dengan pendekatan secaracross sectional berdasarkan survey SDKI tahun 2012 denganjumlah sampel sebanyak 4.618. Hasil didapatkan komplikasi obstetric sebanyak 51,2\% dan terdapat hubungan yang bermakna social ekonomi, paritas, jarak kelahiran, riwayat komplikasi, wilayah tempat tinggal, tempat bersalin, dan kualitas ANC terhadap komplikasi obstetric. Variabel yang berpengaruh riwayat komplikasi $\mathrm{OR}=4,084$, kualitas $\mathrm{ANC} O \mathrm{O}=1,187$, tempat bersalin $\mathrm{OR}=1,517$, jarak kelahiran dan paritas berinteraksi dengan tempat tinggal didesa terhadap komplikasi obstetric.Diharapkan petugas kesehatan terutama bidan dapat meningkatkan kualitas pelayanan ANC dan kemampuan petugas menangani kasus rujukan serta meningkatkan kesiapan ibu dan keluarga untuk mengenal dan mengantisipasi terjadinya komplikasi obstetric terutama pada ibu yang memiliki resiko.

Kata Kunci: Determinan,Komplikasi Obstetri

\section{Corresponding Author:}

Serilaila,

Jurusan Kebidanan Poltekkes Kemenkes Banjarmasin

Jln H. Mistar Cokrokusumo No.1A Banjarbaru

Email :serilaila11@yahoo.co.id
Copyright (C) 2018 Jurnal Skala Kesehatan. Politeknik Kesehatan Banjarmasin All rights reserved 


\section{PENDAHULUAN}

Angka kematian ibu (AKI) di Indonesia dalam kurun waktu 15 tahun tidak menunjukkan perubahan dan malah mengalami kemunduran.Menurut Survei Demografi dan Kesehatan Indonesia (SDKI) tahun 2002-2003 sebesar 307/100.000 Kelahiran Hidup $(\mathrm{KH})$, tahun 2007 sebesar 228/100.000 KH dan tahun 2012 melonjak mencapai $359 / 100.000 \mathrm{KH}$. Angka ini menjadi perdebatan dan tantangan yang besar untuk mengatasi dan mendeteksinya[1].

Banyak faktor yang menyebabkan kematian ibu, hasil penelitian yang dilakukan oleh Dinyain et al., (2014) di Nigeria dari 84 kasus kematian maternal sekitar 71,4\% disebabkan oleh penyebab langsung dan 28,6\% adalah karena penyebab tidak langsung. Adapun penyebab langsung kematian tersebut adalah akibat komplikasi obstetrik berupa perdarahan (30,9\%), aborsi $(23,8 \%)$, dan infeksi $(14,2 \%)$. Selain itu ibu yang mengalami komplikasi obstetri mempunyai risiko 31,9 kali lebih besar untuk terjadi kematian ibu dibandingkan yang tidak mengalami komplikasi obstetri[3].

Kejadian komplikasi obstetri pada masa kehamilan dan persalinan berdasarkan data SDKI antara tahun 2002-2003 dan tahun 2007 rata-rata terjadi peningkatan sebesar 1-4\% [4]. Angka ini sangat berpengaruh terhadap mortalitas karena lebih dari $90 \%$ dari kematian ibu disebabkan komplikasi obstetri yang sering tidak dapat diramalkan pada saat hamil dan terjadi komplikasi saat persalinan, sehingga hal ini dapat memicu tingginya angka kematian ibu berdasarkan SDKI 2012[5].

Faktor resiko terhadap kehamilan dan persalinan yang dapat menimbulkan komplikasi obstetri yaitu jarak kehamilan, penyakit ibu, riwayat komplikasi obstetric sebelumnya, penolong persalinan dan tempat persalinan[6]. Penelitian lain determinan kejadian komplikasi saat persalinan adalah paritas 1/ $\geq 4$ anak, adanya komplikasi kehamilan, adanya riwayat komplikasi persalinan dahulu, adanya masalah dalam mendapatkan pelayanan kesehatan, kunjungan minimal pemeriksaan antenatal, dan penolong persalinan tenaga kesehatan dan tempat persalinan[6]. Faktor yang paling dominan berhubungan dengan kejadian komplikasi persalinan adalah riwayat komplikasi persalinan dahulu dengan odds ratio 5,52[7].Status kesehatan reproduksi berupa umur ibu saat persalinan, paritas, jarak kelahiran, dan riwayat komplikasi obstetridahulu, akses terhadap pelayanan kesehatan, dan perilaku pemanfaatan pelayanan kesehatan merupakan determinan yang berpengaruh terjadinya kesakitan dan kematian pada ibu dikarenakan mengalami komplikasi obstetri [5].

Adanya komplikasi obstetri, maka setiap ibu hamil dianggap berisiko karena diperkirakan dari kehamilan yang normal 15\%-20\% dapat berubah menjadi komplikasi pada saat persalinan[6].Upaya peningkatan pelayanan antenatal yang mampu mendeteksi dan menangani faktor resiko diharapkan dapat menurunkan angka kematian ibu dan juga bayi [8]. Berdasarkan tingginya komplikasi obsteri yang terjadi, maka perlu dilakukan penelitian yang bertujuan untuk mengetahui determinan terjadinya komplikasi obstetri di Indonesia berdasarkan data SDKI tahun 2012. 


\section{BAHAN DAN METODE}

Penelitian ini merupakan studi analitik menggunakan data sekunder yang diperoleh berdasarkan hasil Survei Demografi dan Kesehatan Indonesia (SDKI) tahun 2012 dengan desain Cross Sectional. Populasi penelitian ini adalah wanita yang pernah kawin antara umur 15-49 tahun yang dijadikan sampel penelitian SDKI tahun 2012 yang berjumlah 45.607[9].Sampel penelitian dihitung dengan rumus uji hipotesis dua proporsi populasi dan didapatkan hasil besar sampel sebesar 906 kemudian sampel dikali 2 sehingga didapatkan sampel penelitian yang minimal sebesar 1.832. Selanjutnya sampel diambil dengan cara bertahap dan didapatkan total sampel sebesar 4.615 responden, tahapan tersebut dijelaskan pada Gambar 1. dibawah ini:

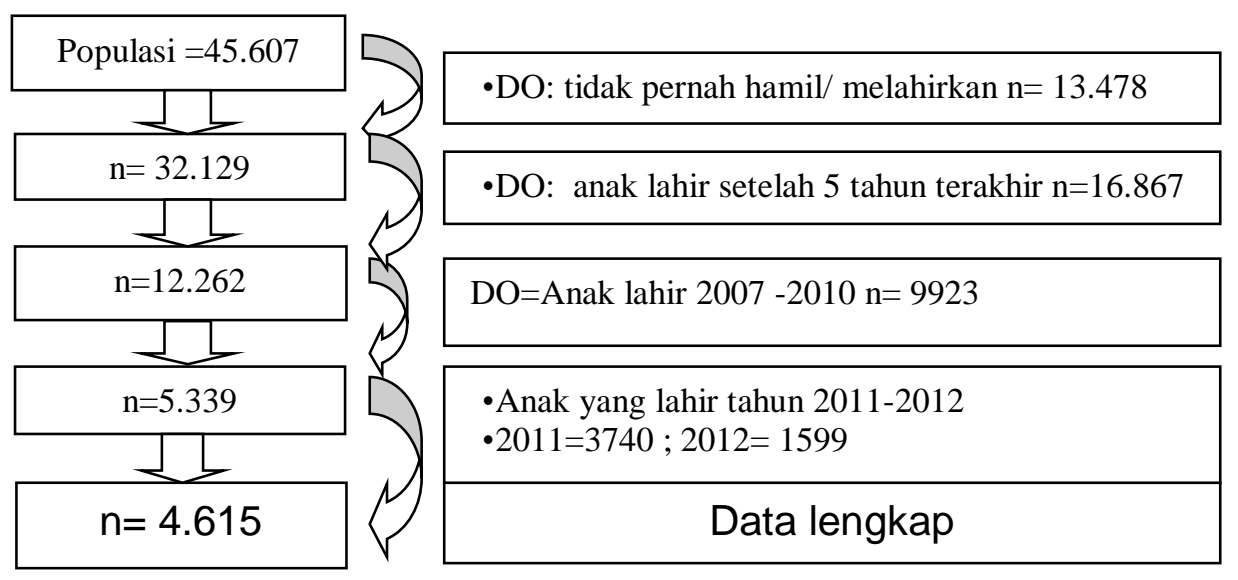

Gambar 1. Skema Pengambilan Sampel Penelitian

Data yang lengkap dianalisis menggunakan komputerisasi secara univariat untuk melihat gambaran masing-masing variabel, sedangkan bivariat dengan uji chi square untuk menilai hubungan antara variabel faktor-faktor risiko dengan komplikasi obstetri. Selanjutnya dilakukan uji multivariat menggunakan regresi logistic yang tujuannya untuk mengetahui variabel riwayat komplikasi, kualitas ANC, tempat bersalin, umur, jarak kelahiran dan paritas yang paling bermakna dan terakhir dilakukan uji interaksi.

\section{HASIL DAN PEMBAHASAN}

Berdasarkan Tabel 1. hasil penelitian didapatkan $51,2 \%$ terjadinya komplikasi obstetri baik pada saat hamil dan atau pada saat persalinan.Pendidikan ibu83,6\% rendah dan $63,3 \%$ social ekonomi tinggi. Sedangkan pada status reproduksi dilihat dari umur $74,6 \%$ pada usia $20-35$ tahun, jarak kelahiran $\leq 2$ tahun sebanyak $54 \%$, paritas multipara $46,8 \%$ dan tidak ada riwayat komplikasi obsterti sebanyak $88,4 \%$. Akses pelayanan yang didapat dilihat dari wilayah tempat tinggal $50,2 \%$ di desa, melakukan kunjungan ANC dengan baik sebanyak $69,2 \%$, dan telah mendapatkan informasi sebanyak $85,7 \%$ tentang komplikasi hamil dan bersalin. Pemanfaatan pelayanan kesehatan $68,8 \%$ telah bersalin ke fasilitas kesehatan, $82,5 \%$ tidak ada persiapan persalinan dan kualitas kunjungan ANC 69,2 dalam keadaan baik. 
Tabel 1. Distribusi Frekuensi Determinan Komplikasi Obstetri(SDKI 2012)

\begin{tabular}{|c|c|c|}
\hline Variabel & Kategori & $\begin{array}{l}\text { Persentase } \\
(n=4615)\end{array}$ \\
\hline \multirow[t]{2}{*}{ Komplikasi obstetric } & Ada & 51,2 \\
\hline & Tidak ada & 48,8 \\
\hline \multirow[t]{2}{*}{ Pendidikan } & Rendah & 83,6 \\
\hline & Tinggi & 16,4 \\
\hline \multirow[t]{2}{*}{ Sosial ekonomi } & Rendah-menengah & 36,7 \\
\hline & Tinggi & 63,3 \\
\hline \multirow[t]{3}{*}{ Umur } & $\leq 19$ tahun & 9,7 \\
\hline & 20-34 tahun & 74,6 \\
\hline & $\geq 35$ tahun & 15,6 \\
\hline \multirow[t]{2}{*}{ Jarak Kelahiran } & $\leq 24$ bulan & 54 \\
\hline & $>24$ bulan & 46 \\
\hline \multirow{3}{*}{ Paritas } & Primipara & 39 \\
\hline & Multipara & 46,8 \\
\hline & Grandemultipara & 14,2 \\
\hline \multirow{2}{*}{$\begin{array}{l}\text { Riwayat komplikasi } \\
\text { obstetric }\end{array}$} & Ada & 11,6 \\
\hline & Tidak ada & 88,4 \\
\hline \multirow{2}{*}{$\begin{array}{ll}\text { Wilayah tempat } \\
\text { tinggal }\end{array}$} & Desa & 50,2 \\
\hline & Kota & 49,8 \\
\hline \multirow[t]{2}{*}{ Kunjungan ANC } & Tidak baik & 30,8 \\
\hline & Baik & 69,2 \\
\hline \multirow{2}{*}{$\begin{array}{ll}\text { Informasi } & \text { tentang } \\
\text { komplikasi } & \end{array}$} & Tidak ada & 14,3 \\
\hline & Ada & 85,7 \\
\hline \multirow[t]{2}{*}{ Tempat bersalin } & Tidak Fasilitas Kesehatan & 31,2 \\
\hline & Fasilitas Kesehatan & 68,8 \\
\hline \multirow{2}{*}{ Persiapan persalinan } & Tidak ada & 82,5 \\
\hline & Ada & 17,5 \\
\hline \multirow{2}{*}{$\begin{array}{l}\text { Kualitas pelayanan } \\
\text { ANC }\end{array}$} & Tidak baik & 42,1 \\
\hline & Baik & 57,9 \\
\hline \multirow{2}{*}{ Penolong persalinan } & Non Tenaga Kesehatan & 2,6 \\
\hline & Tenaga Kesehatan & 97,4 \\
\hline
\end{tabular}


Tabel 2. Menunjukkan jenis komplikasi saat kehamilan dan persalinan yang dapat terjadi pada setiap responden 1 atau lebih kejadian komplikasi. Pada saat kehamilan terdapat $13,7 \%$ dan kasus tertinggi terjadinya perdarahan antepartum, sedangkan pada saat persalinan komplikasi sebanyak $46,5 \%$ yang terbanyak jenis komplikasi akibat partus lama.

Tabel 2. Jenis Komplikasi Kehamilan dan Komplikasi Persalinan(SDKI 2012)

\begin{tabular}{llll}
\hline Variabel & Kategori & $\mathrm{F}$ & $\%$ \\
\hline Komplikasi & Kehamilan & 121 & 2,6 \\
Kehamilan & premature & 179 & 3,9 \\
& Perdarahan & 50 & 1,1 \\
& Demam & 11 & 0,2 \\
& Kejang dan lemah & 365 & 7,9 \\
& Komplikasi lainnya & & \\
\hline Total & & 631 & 13,7 \\
\hline Komplikasi & Perdarahan & 367 & 8,0 \\
Persalinan & Partus lama & 1578 & 34,2 \\
& Demam & 351 & 7,6 \\
& Kejang & 83 & 1,8 \\
& KPD & 693 & 15,0 \\
& Komplikasi lainya & 199 & 4,3 \\
\hline Total & & 2147 & 46,5 \\
\hline
\end{tabular}

Tabel 3. Merupakan hasil analisis bivariat yang dilakukan untuk melihat hubungan antara determinan terhadap terjadinya komplikasi obstetri. Analisis dengan menggunakan uji Chi-Square dinyatakan berhubungan secara statistik bermakna jika nilai $p<0,05$. Hasil didapatkan beberapa faktor yang berhubungan dengan determinan komplikasi obstetric adalah sosial ekonomi, paritas, jarak kelahiran, riwayat komplikasi obstetric, wilayah tempat tinggal, tempat bersalin, dan kualitas pelayanan ANC. Sedangkan tingkat pendidikan, umur, kunjunngan ANC, informasi tentang komplikasi, persiapan persalinan dan penolong persalinan tidak terjadi hubungan secara bermakna. Selain faktor itu dipilih juga variabel kandidat yang akan diuji secara multivariat dengan kriteria $\rho<0,25$ adalah penolong persalinan, persiapan persalinan dan umur. 
Tabel 3. Hubungan Determinan Komplikasi Obstetri di Indonesia(SDKI 2012)

\begin{tabular}{|c|c|c|c|c|c|c|c|}
\hline \multirow[t]{3}{*}{ Variabel } & \multirow[t]{3}{*}{ Kategori } & \multicolumn{4}{|c|}{ Komplikasi obstetric } & \multirow[t]{3}{*}{$P$} & \multirow{3}{*}{$\begin{array}{c}\text { OR } \\
\text { (Cl 95\%) }\end{array}$} \\
\hline & & \multicolumn{2}{|c|}{$\mathrm{Ya}$} & \multicolumn{2}{|c|}{ Tidak } & & \\
\hline & & $\mathrm{n}$ & $\%$ & $\mathrm{~N}$ & $\%$ & & \\
\hline \multirow[t]{2}{*}{ Pendidikan } & Rendah & 1967 & 51,0 & 1892 & 49,0 & \multirow[t]{2}{*}{0,478} & 0,945 \\
\hline & Tinggi & 396 & 52,4 & 360 & 47,6 & & $(0,809-1,1 c$ \\
\hline \multirow{2}{*}{$\begin{array}{l}\text { Social } \\
\text { ekonomi }\end{array}$} & Rendah & 904 & 53,3 & 791 & 46,7 & \multirow[t]{2}{*}{0,03} & 1,144 \\
\hline & $\begin{array}{l}\text { menen } \\
\text { Tingai }\end{array}$ & 1459 & 50 & & 50 & & , \\
\hline \multirow[t]{3}{*}{ Umur } & $\leq 19$ atau $\geq$ & & & & & \multirow[t]{3}{*}{0,248} & 0,9 \\
\hline & 35 tahun & 582 & 49,1 & 588 & 50,3 & & $810-1$ \\
\hline & $20-34$ & 1781 & 51,7 & 1664 & 48,3 & & \\
\hline \multirow[t]{3}{*}{ Paritas } & Primi atau & & & & & \multirow[t]{3}{*}{0,001} & 1,359 \\
\hline & Grande & 1344 & 54,8 & 1109 & 45,2 & & $(1,211-1,527)$ \\
\hline & Mult & 1019 & 47,1 & 1143 & 52,9 & & \\
\hline \multirow{2}{*}{$\begin{array}{l}\text { Jarak } \\
\text { Kelahiran }\end{array}$} & $\leq 2$ ta & 1374 & 55,1 & 1118 & 44,9 & \multirow[t]{2}{*}{$0,001^{*}$} & 1,407 \\
\hline & $>2$ tahun & 990 & 46,6 & 1134 & 53,4 & & $(1,252-1,580)$ \\
\hline \multirow{2}{*}{$\begin{array}{l}\text { Riwayat } \\
\text { komplikasi }\end{array}$} & $\mathrm{Ya}$ & 406 & 75,8 & 131 & 24,4 & \multirow[t]{2}{*}{0,001} & 3,359 \\
\hline & Tidak & 1957 & 48,0 & 2121 & 52,0 & & $(2,733-4,129)$ \\
\hline \multirow{2}{*}{$\begin{array}{l}\text { Wilayah } \\
\text { tempat } \\
\text { tinggal }\end{array}$} & Desa & 1113 & 48,4 & 1187 & 51,6 & \multirow[t]{2}{*}{$0,001^{*}$} & 1,252 \\
\hline & Kota & 1250 & 54,0 & 1065 & 46,0 & & $(1,115-1,405)$ \\
\hline \multirow{2}{*}{$\begin{array}{l}\text { Kunjungan } \\
\text { ANC }\end{array}$} & Tidak baik & 722 & 50,8 & 700 & 49,2 & \multirow[t]{2}{*}{0,721} & 0,975 \\
\hline & Baik & 1641 & 51,4 & 1552 & 48,6 & & $861-1,105)$ \\
\hline \multirow{2}{*}{$\begin{array}{l}\text { Informasi } \\
\text { tentang } \\
\text { komplikasi }\end{array}$} & Tidak & 341 & 51,6 & 320 & 48,4 & \multirow[t]{2}{*}{0,830} & 0,982 \\
\hline & $\mathrm{Ya}$ & 2022 & 51,1 & 1932 & 48,9 & & 33-1,158) \\
\hline \multirow{2}{*}{$\begin{array}{l}\text { Tempat } \\
\text { bersalin }\end{array}$} & Non Fakes & 642 & 43,3 & 817 & 56,7 & \multirow[t]{2}{*}{0,001} & 1,587 \\
\hline & Fakes & 1739 & 54,8 & 1435 & 45,2 & & $(1400-1,799)$ \\
\hline \multirow{2}{*}{$\begin{array}{l}\text { Persiapan } \\
\text { persalinan }\end{array}$} & Tidak ada & 1926 & 50,6 & 1881 & 49,4 & \multirow[t]{2}{*}{0,077} & 0,869 \\
\hline & Ada & 437 & 54,1 & 371 & 45,9 & & $(0,747-1,012)$ \\
\hline \multirow{2}{*}{$\begin{array}{l}\text { Kualitas } \\
\text { pelayanan } \\
\text { ANC }\end{array}$} & Tidak baik & 1030 & 53,1 & 911 & 46,9 & $0,033^{*}$ & 1,137 \\
\hline & Baik & 1333 & 49,9 & 1341 & 50,1 & & 101 \\
\hline $\begin{array}{l}\text { Penolong } \\
\text { persalinan }\end{array}$ & $\begin{array}{l}\text { Non Nakes } \\
\text { Nakes }\end{array}$ & $\begin{array}{l}52 \\
2311\end{array}$ & $\begin{array}{l}44,1 \\
514\end{array}$ & $\begin{array}{l}66 \\
2186\end{array}$ & $\begin{array}{l}55,9 \\
486\end{array}$ & 0,140 & $\begin{array}{r}0,745 \\
(0516-10\end{array}$ \\
\hline linan & Nakes & & 51,4 & 2186 & 48,6 & & $(0,516-1,0$ \\
\hline
\end{tabular}

Keterangan: Tanda "' menunjukkan nilai yang signifikan $(p<0,05)$ 
Tabel 4. Merupakan kandidat yang mewakili dilakukan uji multivariat dengan syarat nilai p $>25$, didapatkan 10 kandidat yaitu sebagai berikut:

Tabel 4. Kandidat Uji Multivariat Detereminan Komplikasi Obstetri

\begin{tabular}{ll}
\hline Variable & $P$ \\
\hline Umur & 0,030 \\
Paritas & 0,001 \\
Jarak kelahiran & 0,685 \\
Tempat melahirkan & 0,001 \\
Sosial ekonomi & 0,984 \\
Wilayah tempat tinggal & 0,246 \\
Riwayat Komplikasi & 0,001 \\
Kualitas ANC & 0,003 \\
Persiapan persalinan & 0,351 \\
Penolong persalinan & 0,240 \\
\hline
\end{tabular}

Tabel 5. Merupakan model akhir hasil analisi multivariat yang dilakukan untuk menilai variabel mana yang paling berpengaruh terjadinya komplikasi obstetri dengan menggunakan uji statistik secara regresi logistic. Hasil penelitian didapatkan variabel yang dapat mempengaruhi terjadinya komplikasi obstetri adalah riwayat komplikasi, kualitas ANC, tempat bersalin, umur, jarak kelahiran dan paritas, selanjutnya jarak kelahiran dan paritas berinteraksi dengan wilayah tempat tinggal di desa. Faktor yang paling dominan yang berpengaruh terhadap terjadinya komplikasi obstetrik adalah riwayat komplikasi obstetri dahulu dengan $p=0,001$ dan $\mathrm{OR}=4,084$ kali dibandingkan dengan ibu yang tidak mengalami riwayat komplikasi sebelumnya.

Tabel 5. Model Akhir Regresi Logistik Determinan Terjadinya Komplikasi Obstetri di Indonesia (SDKI 2012)

\begin{tabular}{lllll}
\hline Variable & $\mathrm{B}$ & $p$ & $\mathrm{OR}$ & $\mathrm{Cl} 95 \%$ \\
\hline Riwayat komplikasi & 1,407 & 0,001 & 4,084 & $3,275-5,093$ \\
Kualitas ANC & 0,171 & 0,006 & 1,187 & $1,050-1341$ \\
Tempat bersalin & 0,417 & 0,001 & 1,517 & $1,322-1,741$ \\
Umur Karak Kelahiran & $-0,161$ & 0,027 & 0,851 & $0,738-0,982$ \\
Jarak & 0,358 & 0,019 & 1,430 & $1,060-1,930$ \\
${ }^{*}$ wilayah & & & & \\
Paritas*wilayah & 0,333 & 0,030 & 1,395 & $1,033-1,885$ \\
\hline Constant & $-0,602$ & & & \\
\hline Keterangan*=interaksi & & & &
\end{tabular}

Hasil uji interaksi menunjukkan bahwa variabel Jarak kelahiran berinteraksi dengan wilayah tempat tinggal ibu. Pengaruh jarak kelahiran terhadap komplikasi obstetri tergantung pada wilayah tempat tinggal ibu. Ibu yang tinggal di desa dengan jarak kelahiran kurang dari 2 tahun berisiko 2,108 kali mengalami komplikasi obstetric 
dibandingkan dengan jarak kelahiran lebih dari 2 tahun, sedangkan ibu yang tinggal di kota dengan jarak kelahiran kurang dari 2 tahun berisiko 1,474 kali mengalami komplikasi kehamilan dibandingkan dengan jarak kelahiran lebih dari 2 tahun.

$\mathrm{OR}=\mathrm{e}^{-\left(\text {constanta }+\beta 1^{*} \text { Jarak }+\beta 2^{*} \text { wilayah }+\beta 3^{*} \text { Jarak }{ }^{*} \text { Wilayah }\right)}$

Risiko lbu Tinggal Di Desa:

$\mathrm{OR}=\mathrm{e}^{-\left(-0,602-0,144^{*} 1-0,263^{*} 0+0,358^{*} 0\right)}$

$\mathrm{OR}=\mathrm{e}^{-(-0,746)}=2,108$

Selanjutnya hasil interaksi pada variabel paritas berinteraksi dengan wilayah tempat tinggal ibu. Pengaruh paritas terhadap komplikasi obstetri tergantung pada wilayah tempat tinggal ibu. Ibu yang tinggal di desa dengan paritas primipara atau grandemultipara berisiko 1,226 kali mengalami komplikasi obstetric dibandingkan dengan ibu multipara, sedangkan ibu yang tinggal di kota dengan paritas primipara atau grandemultipara tidak ada perbedaan risiko dengan multipara dengan hasil risiko protektif sebesar 0,878 kali. Hasil perhitungan tersebut di bawah ini:

$\mathrm{OR}=\mathrm{e}^{-\left(\text {constanta }+\beta 1^{\star} \text { Paritas }+\beta 2^{*} \text { wilayah }+\beta 3^{*} \text { Paritas }{ }^{*} \text { Wilayah }\right)}$

Risiko lbu Tinggal Di Desa:

$\mathrm{OR}=\mathrm{e}^{-\left(-0,602-0,398^{*} 1-0,263^{*} 0+0,358^{*} 0\right)}$

$\mathrm{OR}=\mathrm{e}^{-(-0,204)}=1,226$

\section{Komplikasi Obstetri}

Kejadian komplikasi obstetrik berdasarkan data SDKI tahun 2012 cukup tinggi yaitu sebesar $51,2 \%$ (Tabel.1) dibanding penelitian yang dilakukan oleh Huda (2007) sebanyak 46,8\% juga penelitian yang dilakukan olehSikder et al., (2014) terhadap ibu hamil di pedesaan Bangladesh yang mengalami komplikasi obstretri sebesar $25 \%$. Komplikasi ini cukup tinggi dan meningkat terutama pada saat persalinan sebesar 46,5\% dibandingkan data SDKI 2002 sebesar 36\% [4]dan data SDKI 2007 sebesar $44 \%$ [7]. Tingginya komplikasi ini disebabkan partus lama sebesar $34,2 \%$ (Tabel 2), keadaan ini dapat berakibat dan menimbulkan dehidrasi, infeksi, dan kelelahan sehingga meningkatkan kejadian kematian pada ibu dan janin[12].

\section{Karakteristik Ibu}

Karakteristik ibu pada penelitian ini dinilai melalui pendidikan dan status ekonomi, hasilnya didapatkan sosial ekonomi berhubungan dengan kejadian komplikasi obstetri sedangkan pendidikan tidak berhubungan (Tabel 3). faktor social ekonomi dapat mempengaruhi seseorang terhadap akses pelayanan yang didapat. Social ekonomi mempengaruhi terhadap pemilihan tempat dan penolong persalinan. Sosial ekonomi tinggi dapat mempengaruhi seorang ibu untuk dapat melakukan pemeriksaan yang lebih lengkap sehingga lebih terdeteksi komplikasi yang akan terjadi dan pemilihan penolong persalinan yang sesuai dan memadai sehingga komplikasi obstetric dapat ditekan seminimal mungkin[13].

Dalam penelitian ini pendidikan tidak ada hubungan dengan komplikasi obstetri, walaupun sebagian besar (83,6\%) responden berpendidikan rendah (Tabel.1).Banyaknya pendidikan rendah dapat berpengaruh terhadap upaya seseorang dalam mencari informasi yang lebih banyak untuk menambah pengetahuan yang telah dimiliki sebelumnya.Semakin tinggi tingkat pendidikan yang diperoleh maka semakin tinggi pula tingkat pengetahuan dan kesadaran lbu rumah tangga terhadap reproduksi yang sehat[14]. 


\section{Faktor Status Reproduksi}

Status reproduksi ibu pada penelitian ini dinilai berdasarkan umur ibu saat persalinan, paritas, jarak kelahiran, dan riwayat komplikasi obstetri (kehamilan dan atau persalinan) dahulu. Hasil penelitian umur tidak berhubungan dengan komplikasi obstetri, sedangkan paritas, jarak kelahiran dan riwayat komplikasi memiliki hubungan yang bermakna dengan $\mathrm{p}=0,001$ (Tabel,3).

Umur ibu saat persalinan menentukan kematangan organ reproduksi seseorang, hasil penelitian sebagian besar (74,6\%) usia 20-34 tahun (Tabel 1). Umur tersebut termasuk kategori usia reproduksi sehat, sehingga menurunkan risiko komplikasi obstetri terutama usia 25-29,9 tahun [15]. Hasil penelitian lain didapatkan usia <18 tahun beresiko 1,28 dan >35 tahun beresiko 1,24 kali menimbulkan terjadinya komplikasi obstetri [11].

Jarak kelahiran $\leq 2$ tahun berhubungan yang bermakna menimbulkan komplikasi obstetri dengan $\mathrm{OR}=1,407$ kali dibandingkan jarak kelahiran $>24$ bulan. Hasil penelitian ini sejalan dengan penelitian Larder (2010)wanita dengan interval pendek $(<18$ bulan)antara kehamilannya berisiko 3,4 kali lebih mungkin untuk mengalami komplikasi persalinan dibandingkan dengan interval optimal (18-24bulan). Jarak persalinan $<2$ tahun akan menyebabkan seorang ibu belum cukup waktu untuk memulihkan kondisi tubuhnya setelah melahirkan sebelumnya. Ibu hamil dalam kondisi tubuh kurang sehat ini merupakan salah satu faktor penyebab kematian ibu dan bayi yang dilahirkan serta risiko terganggunya sistem reproduksi. Ibu hamil yang jarak kelahirannya kurang dari dua tahun, kesehatan fisik dan kondisi rahimnya masih membutuhkan istirahat yang cukup. Terlalu dekat jarak kehamilan adalah jarak kehamilan antara satu dengan berikutnya kurang dari 2 tahun atau 24 bulan.Pada ibu dengan jarak kehamilan <24 bulan kondisi rahim ibu belum pulih dan risiko kehamilan pada jarak <24 bulan adalah persalinan preterm [17].

Hasil penelitian yang bermakna selanjutnya adalah paritas, didapatkanhampir sebagian $(46,8 \%)$ responden paritas multipara dan lebih sebagian $(54,8 \%)$ gabungan paritas primi sebesar 39\%dan grandemultipara 14,2\%(Tabel.1) serta menimbulkan resiko sebesar 1,35 kali dibandingkan paritas multipara. Penelitian sama menyatakan grand-multiparitas berhubungan dengan komplikasi persalinan dengan risiko sebesar 2,7 kali dibandingkan dengan ibu multipara.Grandemultiparitas berisiko mengalami komplikasi obstetri berupa ketuban pecahdini 16,2\%, penyakithipertensipada kehamilan27,1\%, plasenta previa15,3\% dankomplikasimedis lainnya, 23,2\% [18].

Kejadian ini akan diperberat bila ibu primipara atau grandemultipara berada diwilayah desa, hasil uji interaksi menunjukkan variabel paritas berinteraksi dengan wilayah tempat tinggal ibu. Pengaruh tersebut terutama pada ibu yang tinggal di desa dengan risiko 1,2 kali mengalami komplikasi dibandingkan ibu multipara tinggal di perkotaan. Hal ini jadi perhatian bagi petugas kesehatan dalam upaya pencegahan terjadi risiko komplikasi dengan mengenal tanda-tanda bahaya berupa komplikasi obstetri antara lain pre eklamsia, perdarahan, dan infeksi dengan melakukan tindakan antisipasi dalam penanganan kegawatdaruratan obstetrik baik ditingkat dasar dan melakukan rujukan yang tepat sesuai protap yang berlaku[19].

Status reproduksi selanjutnya dilihat dari riwayat komplikasi obstetrik, hasil 
penelitian dari ibu yang memiliki riwayat komplikasi saat hamil atau bersalin sebelumnya lebih dari sebagian $(75,8 \%)$ mengalami komplikasi obstetri dan berisiko 3,369 kali dibandingkan yang tidak memiliki riwayat komplikasi. Hasil penelitian yang sama oleh Diana, et al (2013) didapatkan riwayat komplikasi berisiko sebesar 5,41 kali dibandingkan dengan tidak memiliki riwayat komplikasi kehamilan sebelumnya.Adanya riwayat komplikasi sebelum hamil atau persalinan ini dapat memicu timbulnya komplikasi obstetric akibat status kesehatan ibu yang tidak baik sehingga dapat meningkatkan terjadinya komplikasi.

Riwayat komplikasi obstetri merupakan faktor yang paling dominan berpengaruh terhadap komplikasi obstetri setelah dilakukan uji multivariat dengan risiko 4,084 kali dibandingkan tidak memiliki risiko. Ibu hamil yang sebelumnya mengalami perdarahan post partum maka persalinan berikutnya berpotensi kejadian serupa berulang perdarahan obstetric berupa placenta previa, solusio plasenta, atonia uteri dan lain-lain [20]. Salah satu upaya yang efektif untuk mengendalikannnyaadalah dengan cara deteksi dini terhadap riwayat komplikasi sebelumnya dengan pemeriksaan teratur dan persalinan ditolong oleh petugas kesehatan dan difasilitas kesehatan.

\section{Faktor Akses Pelayanan Kesehatan}

Akses pelayanan kesehatan mencakup wilayah tempat tinggal, kualitas pelayanan antenatal yang didapat, informasi tentang komplikasi kehamilan dan persalinan. Hasil penelitian didapatkan wilayah tempat tinggal mendapatkan nilai $\mathrm{p}=0,001$ yang berarti responden yang bertempat tinggal di desa lebih cenderung menimbulkan komplikasi obstetri dibandingkan perkotaan. Tempat tinggal di perdesaan lebih besar risiko untuk mengalami kehamilan dengan keterlambatan, karena di perdesaan jumlah, jenis dan pelayanan di fasilitas kesehatan masih terbatas. Minimnya tenaga kesehatan di perdesaan bisa juga menjadi salah satu faktor yang mengakibatkan kurangnya tenaga penyuluh atau tenaga yang memberikan informasi penting terkait dengan risiko kehamilan dan persalinan kepada masyarakat. Oleh sebab itu masyarakat khususnya ibu menjadi tidak paham akan bahaya yang mengancam keselamatan jiwanya jika mereka hamil atau melahirkan di usia yang terlalu muda atau terlalu tua [21].

Kualitas pelayanan antenatal yang dinilaiadalah terpenuhi syarat pelayanan yang diberikan minimal $5 \mathrm{~T}$,hasil penelitian didapatkan lebih sebagian $(53,1 \%)$ responden tidak memenuhi standardan secara statistik ada hubungan yang bermaknadengan menimbulkan risiko komplikasi obstetri sebesar 1,137kali (Tabel 2). Keadaan ini didukung oleh kajianUnicef (2012) kualitas pelayanan antenatal di Indonesia belum memadai dan baru 20\% perempuan hamil mendapatkan 5 intervensi (5T) yang lengkap dan Propinsi Yogyakarta yang cakupan antenatalnya tertinggi ternyata layanan $5 \mathrm{~T}$ nya hanya mencapai 58\%. Pelayanan antenatal yang tidak memadai dapat memicu terjadinya kematian ibu karena tidakterdeteksinya dan mencegah adanya komplikasi obstetric serta penanganan secara cepat dan memadai[23].

Akses terhadap pelayanan pada lbu hamil antara lain adalah diperolehnya informasi tentang komplikasi, hasil penelitian didapat hampir seluruhnya $(85,7 \%)$ telah mendapatkan informasi (Tabel 1), namun sebagian besar 51,1\% mengalami komplikasi obstetri dan secara statistik didapatkan tidak ada hubungan yang bermakna antara informasi tentang komplikasi dengan kejadian komplikasi obstetri. Seringkali informasi 
yang diberikan oleh tenaga kesehatan tidak diterapkan atau digunakan oleh ibu karena tidak dimengerti atau tidak sesuai dengan kondisi ataupun kebutuhan mereka. Hal ini dapat terjadi karena komunikasi yang terlaksana antara tenaga kesehatan dan ibu hanya satu arah sehingga ibu tidak mendapatkan pemahaman dan dukungan yang cukup untuk menerapkan informasi. Untuk itu diperlukan petugas yang memiliki kemampuan dalam berkomunikasi dan konseling dengan memperhatikan prinsip-prinsip komunikasi dan menggunakan bahasa yang sederhana dan mudah dimengerti [23].

\section{Faktor Pemanfaatan Pelayanan Kesehatan}

Pemanfaatan pelayanan kesehatan antara lain kunjungan pemeriksaan antenatal yang dilakukan, persiapan persalinan, pemilihan penolong persalinan, dan pemilihan tempat persalinan. Kunjungan pemeriksaan antenatal adalah pemeriksaan kehamilan pada tenaga kesehatan dengan frekuensi kunjungan pemeriksaan minimal 4 kali yaitu 1 kali pada trimester I, 1 kali pada trimester II, 2 kali pada trimester III. Hasil penelitian didapatkan sebagian besar $(69,2 \%)$ telah melakukan kunjungan sesuai standar, namun kejadian komplikasi obstetric tidak terlalu berbeda dan sedikit meningkat pada ibu yang melakukan ANC sesuai standar yaitu: $51,4 \%$ dan $50,8 \%$ pada ibu yang tidak sesuai. Angka ini setelah dianalisis secara bivariat diperoleh nilai $p=0,721$ dan $O R=0,975$, berarti angka ini menunjukkan tidak ada hubungan yang bermakna antara kunjungan ANC dengan kejadian komplikasi obstetri. Penelitian yang sama didapatkan kunjungan antenatal yang tidak sesuai standar tidak berhubungan dengan terjadinya komplikasi obstetric dengan nilai $\rho=0,488$ [6].Penelitian lain yang berbedadidapatkan ibu hamil yang melakukan ANC dengan frekuensi $<4$ kali dan tidak teratur sesuai jadwal serta tidak mendapatkan pelayanan $5 \mathrm{~T}$ diperoleh nilai $\mathrm{p}$ value $=0,016, \mathrm{OR}=2,588$ [24]. Keadaan ini dimungkinkan terjadi karena banyak faktor yang mempengaruhi terjadinya komplikasi obsteri dan bukan hanya karena ketidakteraturan kunjungan tetapi yang penting adalah kualitas dari kunjungan sehingga dapat mendeteksi lebih awal terhadap kemungkinan terjadinya komplikasi.

Persiapan persalinan berupa tempat, penolong, biaya, donor dan transfortasi penting sekali direncanakan sejak kehamilan. Berdasarkan data SDKI 2012 ditemukan $82,5 \%$ ibu telah mempersiapkan tetapi lebih dari sebagian $(54,1 \%)$ mengalami komplikasi obstetric. Hasil analisis menunjukkan bahwa tidak terdapat hubungan bermakna antara persiapan persalinan dan kejadian komplikasi dengan nilai $p=0,077$, $\mathrm{OR}=0,869$.

Penyebab sebagian besar kematian ibu di Indonesia dapat ditelusuri dari 'tiga terlambat' yaitu: terlambat mengambil keputusan untuk merujuk ibu hamil ke fasilitas kesehatan yang mampu menangani komplikasi, terlambat mendapatkan transportasi ke fasilitas kesehatan, dan terlambat mendapatkan pelayanan kesehatan atau transfusi darah yang tepat pasca kedatangan ke fasilitas kesehatan. Pencegahan terhadap keterlambatan tersebut hasil penelitian yang dilakukanAfdal \& Wahiduddin (2012) bahwa persiapan persalinan berupa perencanaan persalinan berpengaruh terhadap pencegahan komplikasi dengan hasil persiapan terhadap tempat persalinan nilai $\mathrm{OR}=1,258$, penolong persalinan $\mathrm{OR}=13,941$, biaya $\mathrm{OR}=3,764$, donor dengan $\mathrm{OR}=6,652$, dan transportasi $\mathrm{OR}=6,231$, sebagai upaya pencegahan komplikasi.

Penolong persalinan yang terampil dapat mempengaruhi dalam menangani kasus dan hasil penelitian didapatkan tidak terdapat hubungan bermakna antara 
penolong persalinan terhadap kejadian komplikasi obstetric. Hasil univariat didapatkan hampir seluruh $(97,4 \%)$ ibu telah bersalin kepada tenaga kesehatan terutama bidan. Hal ini dapat mendukung tidak bermakna pengaruhnya, namun penelitian Diana, et al (2013) yang menyatakan ada hubungan yang bermakna antara penolong persalinan dengan kejadian komplikasi obstetric dengan $p=0,001$, berarti ibu yang melahirkan dengan non tenaga kesehatan atau dukun beranak cenderung akan menimbulkan komplikasi dibandingkan dengan tenaga kesehatan.

Tenaga kesehatan yang profesional seperti dokter dan bidanadalah garda terdepan dalam mendeteksi kemungkinan risiko, melakukan asuhan yang tepat dan melakukan rujukan dini tepat waktu kasus gawat darurat obstetri serta mampu memberikan pertolongan segera dan adekuat terhadap kasus gawat darurat obstetri di rumah sakit rujukan.Adanya tenaga penolong yang terampil pada saat sebelum, selama dan sesudah persalinan telah terbukti mempunyai peran dalam menurunkan kematian ibu terutama dalam menghadapi trias penyebab kematian ibu[19].

Hasil penelitian pada tempat bersalin sebagian besar $(68,8 \%)$ ibu telah dilakukan pada fasilitas kesehatan, namun kejadian komplikasi obstetric lebih sebagian $(54,8 \%)$ terjadi tempat persalinan di fasilitas kesehatan. Keadaan ini dapat terjadi karena ibu yang mengalami komplikasi obstetric akan dirujuk ke fasilitas kesehatan seperti Polindes, Klinik, Puskesmas atau ke rumah sakit. Hasil analisis bivariat terdapat hubungan yang bermakna antara tempat persalinan dengan kejadian komplikasi obstetric $(\rho=0,000, O R=1,587)$. Hasil penelitian yang sama bahwa tempat persalinan difasilitas kesehatan berpengaruh terhadap komplikasi obstetric dengan resiko 1,18 kali dibandingkan ibu yang melahirkan pada tidak di fasilitas kesehatan[10].

Rumah sakit merupakan tempat persalinan yang dapat mencegah komplikasi obstetri dan menurunkan resiko kematian ibu dan anak, namun hasil penelitianSimbolon, et al (2013) Rumah sakit di Indonesia menunjukkan bahwa proporsi kematian ibu karena pendarahan $>1 \%$ paling banyak berada di rumah sakit kelas $D$ $(39,3 \%)$. Proporsi kematian ibu karena preeklamsia $>10 \%$ paling banyakberada di rumah sakit kelas $\mathrm{A}(75 \%)$. Proporsi kematian ibu karena sepsis $>0,2 \%$ paling banyak ada di rumah sakit kelas D (45,8\%). Proporsi kematian karena seksio secaria $>20 \%$ paling banyak berada di rumah sakit kelas B $(57,2 \%)$. Hal ini terjadi akibat sebagian besar $(66,3 \%)$ rumah sakit pemerintah di Indonesia dengan kinerja kurang optimal pada pelayanan kesehatan ibu dan anak (KIA). Hal ini perlu menjadi perhatian bagi tenaga kesehatan untuk mampu secara profesional dalam menangani kasus-kasus kegawatdaruratan terutama di rumah sakit sebagai pusat rujukan dan mencegah ketermbatan dalam penanganan.

\section{KESIMPULAN}

Berdasarkan hasil penelitian tentang determinan komplikasi obstetri berdasarkan data SDKI tahun 2012, dapat disimpulkan bahwa terjadi komplikasi obstetricsebanyak $51,2 \%$ dan terdapat hubungan yang bermakna social ekonomi, paritas, jarak kelahiran, riwayat komplikasi, wilayah tempat tinggal, tempat bersalin, dan kualitas ANC terhadap komplikasi obstetric. Variabel yang berpengaruh riwayat komplikasi $\mathrm{OR}=4,084$, kualitas ANC $\mathrm{OR}=1,187$, tempat bersalin $\mathrm{OR}=1,517$, jarak kelahiran dan paritas berinteraksi dengan tempat tinggal didesa terhadap komplikasi obstetri. 


\section{SARAN}

Petugas kesehatan terutama bidan untuk melakukan deteksi dini terhadap risiko kehamilan dan persalinan terutama pada wanita dengan riwayat komplikasi sebelumnya dan meningkatkan kualitas ANC serta mengantisipasi pertolongan persalinan ditempat fasilitas kesehatan terutama pada wanita dengan jarak kelahiran kurang dari dua tahun dan paritas primi atau grandemultipara yang bertempat tinggal di desa.

\section{UCAPAN TERIMAKASIH}

Terimakasih kami ucapkan kepada Poltekkes Kemenkes Bengkulu yang telah memberikan bantuan dana dan dukungan sehingga terselesaikan penelitian ini dan BKKBN sebagai sumber data SDKI 2012.

\section{DAFTAR PUSTAKA}

[1] S. Budiantoro, "Angka Kematian Ibu (AKI) Melonjak, Indonesia Mundur 15 Tahun," Prakarsa, p. 2, 2013.

[2] A. Dinyain, G. Olutoyin Omoniyi-Esan, O. O. Olaofe, D. Sabageh, A. O. Komolafe, and O. S. Ojo, "Autopsy-certified maternal mortality at lle-Ife, Nigeria," Int. J. Womens. Health, vol. 6, no. 1, pp. 41-46, 2014.

[3] D. Sarwani and S. Nurlela, "Analisis Faktor Risiko Kematian Ibu (Studi Kasus di Kabupaten Banyumas)," J. Kesmasindo, vol. 6, no. 1, pp. 1-11, 2013.

[4] S. Djaja and T. Afifah, "Pencapaian Dan Tantangan Status Kesehatan Maternal Di Indonesia," J. Ekol. Kesehat., vol. 10, no. 1 Mar, pp. 10-20, 2011.

[5] Saifuddin, Ab; Adriaansz, G., Wiknjosastro, H., Waspodo, D., Buku Acuan Nasional Pelayanan Kesehatan Maternal dan Neonatal. Jakarta: Yayasan Bina Pustaka Sarwono Prawirohardjo., 2009.

[6] Diana, H. Sukandar, and B. Handono, "Analisis Faktor-Faktor yang Berhubungan dengan Komplikasi Obstetri Ibu dan Bayi di Kecamatan Parongpong Kabupaten Bandung Barat," pp. 118, 2013.

[7] O. S. Simarmata and Y. Armagustini, "Detreminan Kejadian Komplikasi Persalinan di Indonesia (Analisis Data Sekunder Survei Demografi Kesehatan Tahun 2007) Determinant Factors on Delivery Complication in Indonesia , 2007 ( in-dept analysis of Demographic and Health Survey 2007," vol. 2015, 2015.

[8] Kementerian kesehatan RI, Rencana Aksi Penurunan Angka Kematian Ibu. Jakarta: Kementerian Kesehatan RI, 2013.

[9] Kementerian kesehatan RI, "RISKESDAS2013 dalam Angka dan Buku," 2013, pp. 70-76.

[10] L. N. Huda, "Hubungan Status Reproduksi, Status Kesehatan, Akses Pelayanan Kesehatan dengan Komplikasi Obstetri di Banda Sakti, Lhokseumawe Tahun 2005," Kesmas Natl. Public Heal. J., vol. 1, no. 6, pp. 275-281, 2007.

[11] S. S. Sikder, A. B. Labrique, A. A. Shamim, H. Ali, S. Mehra, L. Wu, S. Shaikh, K. P. West, and P. Christian, "Risk factors for reported obstetric complications and near misses in rural northwest Bangladesh: Analysis from a prospective cohort study," BMC Pregnancy Childbirth, vol. 14, no. 1, pp. 1-13, 2014.

[12] H. Wiknjosastro, IImu Kebidanan. Jakarta: Yayasan Bina Pustaka Prawiroharjo, 2010.

[13] R. Ekawati, "Karakteristik Sosial Ekonomi dan Kesehatan Maternal," Kesmas, J. Kesehat. Masy. Nas., vol. 6, no. 3, pp. 133-139, 2011.

[14] Asiah MD, "Hubungan Tingkat Pendidikan Dengan Pengetahuan Kesehatan Reproduksi lbu Rumah Tangga di Desa Rukoh Kecamatan Syiah Kuala Banda Aceh," Unsyiah Darussalam, pp. $1-4,2013$.

[15] J. Timofeev, U. M. Reddy, C.-C. Huang, R. W. Driggers, H. J. Landy, and S. K. Laughon, "Obstetric complications, neonatal morbidity, and indications for cesarean delivery by maternal age.," Obstet. Gynecol., vol. 122, no. 6, pp. 1184-95, 2013.

[16] G. V. M. Larder C, "Interpregnancy Intervals, MI PRAMS 2007," MI PRAMS Deliv., vol. 9, no. July, pp. 3-6, 2010. 
[17] BKKBN, Keluarga Berencana dan Kontrasepsi. Jakarta: Pustaka Sinar Harapan, 2007.

[18] A. S. A. Adeola F. Afolabi, "Grand-multiparity: Is it still an Obsteetric Risk?," J. Obstet. Gynocologi, vol. 1, no. 3, pp. 411-415, 2013.

[19] M. T. Chalid, "Upaya Menurunkan Angka, Kematian lbu: Peran Petugas Kesehatan," PT.Gakken Heal. Educ. Indones., pp. 1-8, 2016.

[20] I. Manuaba, C. Manuaba, and F. Manuaba, Pengantar Kuliah Obstetri. Jakarta: EGC, 2009.

[21] P. H. Sari, D. Hapsari, I. Dharmayanti, and N. Kusumawardani, "Faktor-Faktor Yang Berpengaruh Terhadap Risiko Kehamilan '4 Terlalu (4-T)' Pada Wanita Usia 10-59 Tahun (Analisis Riskesdas 2010)," Media Penelit. dan Pengemb. Kesehat., vol. 24, no. 3, pp. 143-152, 2015.

[22] Unicef, "Kesehatan Ibu \& Anak," UNICEF Indones., no. Gambar 2, pp. 1-2, 2012.

[23] Kementerian kesehatan RI, "Buku Saku Pelayanan Kesehatan Ibu Di Fasilitas Kesehatan Dasar Dan Rujukan," E-book, pp. 22-34, 2013.

[24] Y. Misar, Zulkifli, Masni, and Andi Zulkifli, "Faktor Risiko Komplikasi Persalinan Pada Ibu Melahirkan di Kabupaten Gorontalo Utara Tahun 2012," pasca.unhas.ac.id/jurnal/files/032f3fbb5039c51e91e59b0c0bbfda22.pdf, pp. 1-12, 2012.

[25] M. Afdal, Rismayanti, and Wahiduddin, "Faktor Risiko Perencanaan Persalinan terhadap Kejadian Komplikasi Persalinan di Kabupaten Pinrang Tahun 2012," pp. 1-14, 2012.

[26] D. Simbolon, D. Chalidyanto, and Ernawati, "Determinan Kinerja Pelayanan Kesehatan Ibu Dan Anak Di Rumah Sakit Pemerintah Indonesia (Analisis Data Rifaskes 2011)," J. Kebijak. Kesehat. Indones., vol. 2, no. 04, pp. 202-214, 2013. 